\title{
JUBILEE MEETING OF THE GLASGOW GEOLOGICAL SOCIETY.
}

S1r,-The Geological Society of Glasgow, instituted in 1858, has now entered the fifty-first year of its existence. The Council have made arrangenents to celebrate the event by holding a Jubilee meeting in (ilasgow Unirersity on January 28, 1909. Sir Archibald Geikie, P.R.S., the senior member of the Society, has promised to be present and deliver an address. Sir Donald MacAlister, Dr. Teall (Director of the Geological Surrey of Great Britain), Dr. Horne, Dr. Peach, and other eminent men of science will take part in the proceedings. A history of the work of the Society, with biographical notices of prominent members, is being prepared under the editorship of the Secretaries, Messrs. Peter Macnair, F.R.S.E., F.G.S., and Frederick Mort, M.A., B.Se., F.G.S., F.R.S.G.S., who hope to issue the book by the end of the sear.

Fmederick Mort, Hon. Sec.

\section{OPITUARY.}

\section{PROFESSOR ALBERT JEAN GAUDRY,}

\author{
Memb. Inst. France; For. Memb. R. S.; For. Memb. Geol. Soc.
}

\section{Bons 18:7.}

Died November $2 \pi, 1908$.

WE regret to record the decease of the eminent Professor of Palæontology, Professor Albert J. Gaudry, who for fifty years had been connected with the Museum of Natural History in the Jardin des Plantes, and whose life, accompanied by his portrait, we published in the Grological Magazne for February, 1903, pp. 49-53, on the occasion of his retirement from office. We learn from his successor, Professor Marcellin Boule, that Professor Gaudry had been in failing liealth for some time, but up to the last his mental activity had never deserted him, and he had just lately published his "Fossiles de Patagonie. De l'économie dans la Nature" (Ext. de Annales de Paléontologie, t. iii, pp. 44-60, 71 figures, Paris, 1908). His memory will long be cherished by a very large circle of fellowworkers and personal friends, to whom he was endeared by his many acts of kindness and by the natural amiability of his disposition to all with whom he came in contact.

\section{JOSEPH LOMAS, F.G.S.}

WE deeply regret to have to record the death of $\mathrm{Mr}$. Joseph Lomas, F.G.S., who perished in a railway accident near Biskra, Algeria, on December 18, 1908. $\mathrm{Mr}$. Lomas was visiting Algeria to study desert conditions for a Committee of the British Association appointed at Dublin last September. We hope to give some account of his lifework next month. 